\title{
熱伝導を考慮したブラダ形アキュムレータの数学モデル*
}

\author{
宮下修人**, 眞 田一志***
}

\section{A Mathematical Model of a Bladder-type Accumulator Considering Heat Conduction}

\author{
Shuto MIYASHITA, Kazushi SANADA
}

\begin{abstract}
Accumulator is an important component for oil-hydraulic circuits. It is used for storing energy, absorbing pulsation flow, and suppressing surge pressure. For predicting accumulator performance, mathematical models of the accumulator have been investigated by many researchers. In the mathematical models of accumulator, an equation of state of gas, thermodynamics, and heat transfer have been considered. The aim of this paper is to propose a mathematical model of bladder-type accumulator considering heat conduction effect inside rubber membrane. Experiments were carried out using a bladder-type accumulator which was connected to a piston-type accumulator. The bladder-type accumulator was prefilled first and then discharged, the piston-type accumulator was charged by the oil discharged from the bladder-type accumulator. Discharging process of the bladder-type accumulator and charging process of the piston-type accumulator were measured simultaneously. The accumulator model proposed was validated by measured date of the experiments.
\end{abstract}

Key words : Accumulator, Modeling, Oil hydraulics, Van der Waals equation, Heat conduction

\section{1. 緒言}

アキュムレータは，エネルギー貯蔵，脈動吸収，サージ 圧抑制などに広く利用されており, 油圧システムの重要な 機器の一つである．気体式アキュムレータに充填されてい る窒素ガスは, 充填・放出に従って, 圧縮・膨張を行う. 窒素ガスと周囲との間の熱伝達の影響で, 窒素ガスの温度 と圧力が変化する. 熱力学的な考察から熱時定数が, Otis ${ }^{1)}$ によって提案された，その論文では，実在気体モデルとし てBeattie-Bridgeman方程式 ${ }^{2)}$ が利用された. ピストン形ア キュムレータの熱時定数の值が, 実験的に求められてい る314).これらのアキュムレータモデルは, ハイブリッド車 両のエネルギー回生回路の研究5)6)にも適用された。 Rupprecht ${ }^{7)}$ は, ピストン形アキュムレータだけでなく, ブ ラダ形およびベローズ形のアキュムレータについて, 熱時 定数の值を測定し, 熱時定数を充填圧力の関数として表し た．充填過程では熱対流の影響によって熱時定数が変化す ることを考慮し, Bender $ら^{8)}$ は, 熱時定数の実験式として, 充填圧力, ガス体積, 経過時間の関数を提案した. 一方,

\footnotetext{
*平成29年 9 月 1 日 原稿受付

**東京工業大学大学院理工学研究科

(所在地 : 東京都目黒区大岡山 $2-12-1$ )

(E-mail : miyashita.s@irs.ctrl.titech.ac.jp)

***横浜国立大学大学院工学研究院

(所在地 : 神奈川県横浜市保土ケ谷区常盤台76-5)

(E-mail : sanada-kazushi-sn@ynu.ac.jp)
}

さまざまなタイプのアキュムレータの特性を比較し, ゴム 製のブラダがある程度の断熱効果を持っていることが, 実 験的に示されている ${ }^{9)}$. 参考文献10)では, 風力発電向けの ピストン形アキュムレータの実験とシミュレーションを行

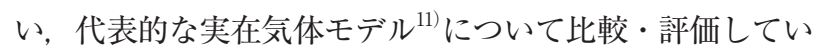
る. これらの従来の研究では, Otisが提案した熱時定数が 用いられており, 窒素ガスと周囲との熱伝達を近似するモ デルが利用されている，しかし，特に，広く利用されてい るブラダ形アキュムレータの場合, 窒素ガスはゴム製のブ ラダに封入されており, ブラダのゴムを介して, 窒素ガス と周囲との間で熱エネルギーが移動する. 従来の熱時定数 を用いたモデルでは, 熱エネルギーの移動を熱伝達として モデル化しており，ブラダのゴム内部における熱伝導の影 響は考慮されていない.

一方, 油圧ショベルのエネルギー回生回路にアキュム レータを利用する方法が注目されているが, アキュムレー 夕の効率向上が課題となっている. アキュムレー夕の効率 は, アキュムレータから周囲に熱エネルギーが散逸するこ とによるエネルギー損失によって定まる，そのため，エネ ルギー損失を明らかにすること, ならびにエネルギー損失 を低減する方策を確立するためには, 熱エネルギーが散逸 する過程すなわち窒素ガスからブラダおよび容器壁を通じ て熱エネルギーが周囲に散逸して損失になる物理現象を解 明する必要がある。

ブラダ形アキュムレータの物理的なモデルの構築のため には，ブラダ内部の熱伝導による熱エネルギーの移動をも 考慮したモデルの構築が必要である. そこで, 本研究では, 
ゴム製ブラダの厚さ方向の熱伝導を考慮した，ブラダ形ア キュムレータの数学モデルを提案する．窒素ガスとブラダ の接触面では熱伝達を考慮し，ブラダのゴムの内部では厚 さ方向の 1 次元熱伝導を考慮した. 窒素ガスの状態変化に ついては，さまざまな実在気体モデルの基礎となっている van der Waals方程式を利用した. van der Waals方程式は, 他の実在気体モデルと比較して，数学的な扱いが比較的容 易であり，等温変化だけでなく断熱変化の式が示されてい る. 本研究では, ブラダ形アキュムレータとピストン形ア キュムレータを接続した試験装置を製作し，充填ならびに 放出の実験を行った．これらの実験結果を，本数学モデル の検証のために用いた。

第 2 章で，主な記号を示す．第 3 章で，本研究で用いる 実在気体モデルであるvan der Waals方程式の概要を示す. 第 4 章で, ピストン形アキュムレータのモデルを示した後, ブラダ形アキュムレータのモデルを提案する．第 5 章では アキュムレータの実験装置について述べ，第 6 章では，実 験結果をもとにアキュムレータモデルの有効性を示す。第 7 章は，本研究で得られた成果をまとめて，結言とする.

\section{2. 主な記 号}

熱伝達に関わる表面積

van der Waals方程式のパラメータ

van der Waals方程式のパラメータ

ゴムの比熱

定容比熱

van der Waalsの断熱変化の指数

熱伝達係数

ゴムの熱伝導率

ブラダのゴムの厚さ

モル数

絶対圧力

臨界圧力

熱エネルギー

気体定数

絶対温度

臨界温度

ブラダのゴム内の絶対温度

$T_{w}$ 壁面の絶対温度

$t \quad$ 時間

$V \quad$ 体積

$v_{c} \quad$ 臨界比体積

$x$ 厚さ方向の座標

$\alpha$ 熱拡散係数

$\gamma$ 数值計算式の係数

$\rho_{r} \quad$ ゴムの密度

$\Delta t$ 時間刻み
$\Delta x \quad$ 厚さ方向の刻み幅

添字

0 初期值

\section{3. van der Waals方程式の概要}

実在気体モデルの基礎に位置づけられるvan der Waals方 程式は, 次式で表される.

$$
\begin{aligned}
& \left(P+\frac{a m^{2}}{V^{2}}\right)(V-m b)=m R T \\
& \text { パラメータ } a \text { と } b \text { は, } \\
& a=\frac{9}{8} R v_{c} T_{c} \\
& b=\frac{1}{3} v_{c}
\end{aligned}
$$

の式で表され, Table 1に示す窒素ガスの臨界定数から求め られる.

Table 1 Nitrogen gas properties

\begin{tabular}{|l|c|l|}
\hline Critical pressure & $P_{c}$ & $3.394388 \mathrm{MPa}$, abs. \\
\hline Critical specific volume & $v_{c}$ & $9.003 \times 10^{-5} \mathrm{~m}^{3} / \mathrm{mol}$ \\
\hline Critical temperature & $T_{c}$ & $126.1 \mathrm{~K}$ \\
\hline Gas constant & $R$ & $8.314501 \mathrm{~J} /(\mathrm{mol} \mathrm{K})$ \\
\hline Specific heat at constant volume & $C_{v}$ & $20.8 \mathrm{~J} /(\mathrm{mol} \mathrm{K})$ \\
\hline
\end{tabular}

等温過程の方程式は，温度一定として次式で表される.

$$
\left(P+\frac{a m^{2}}{V^{2}}\right)(V-m b)=\text { const. }
$$

一方，断熱過程の式は,

$$
\left(P+\frac{a m^{2}}{V^{2}}\right)(V-m b)^{H}=\text { const. }
$$

で表わされ，断熱変化の指数 $H$ は次式で表されることが知 られている.

$$
H=\frac{R}{C_{v}}+1
$$

アキュムレータが通常使用される温度は，この臨界温度 より遙かに高い。窒素ガスの圧力は, 臨界圧力より高い場 合が多い。このことは，これらの条件下ではアキュムレー 夕内に充填されている窒素ガスは, 超臨界状態で存在して いることを示唆している. この場合, 理想気体の状態方程 式ではなく，実在気体の状態方程式を適用する必要がある. 実在気体の状態方程式には，さまざまな方程式が提案され ているが, van der Waals方程式は多くの実在気体のもとと なった方程式である。 また，解析的な取り扱いが容易であ り，等温式 (式(4)) と断熱式 (式(5)) も既知である。この ような理由から，本論文では，van der Waals方程式を利用 した. 


\section{4. アキュムレータモデル}

\section{1 ピストン形アキュムレータ}

はじめに, ピストン形アキュムレータの数学モデルの概 要を示す. ピストン形アキュムレータでは, Fig. 1に示す ように, 窒素ガスがアキュムレータの容器に直接接触して いる．鋼鉄製の容器の壁は，熱容量が十分大きいので，壁 の温度 $T_{w}$ は周囲の温度と等しく, 一様であると仮定する. 窒素ガスと容器の壁との間の熱伝達は次式で表される.

$$
\frac{d Q}{d t}=h A\left(T_{w}-T\right)
$$

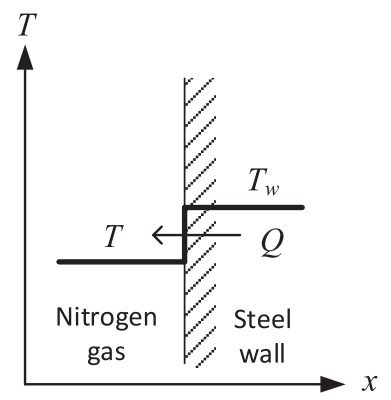

Fig. 1 Heat transfer between nitrogen gas and steel wall of piston-type accumulator

\section{2 ブラダ形アキュムレータ}

ブラダ形アキュムレータの, 窒素ガス, ゴム製ブラダ, および容器の壁面を, Fig. 2のようにモデル化する. ブラ ダ内部の温度 $T_{r}(x, t)$ は, 厚さ方向の位置 $x$ と時間 $t$ の関数 である.ブラダのゴムの内部の温度分布による 1 次元熱伝 導を次式でモデル化する.

$$
\frac{\partial T_{r}(x, t)}{\partial t}=\alpha \frac{\partial^{2} T_{r}(x, t)}{\partial x^{2}}
$$

ここで，熱拡散係数 $\alpha$ は,

$$
\alpha=\frac{k}{C_{r} \rho_{r}}
$$

と表される. 窒素ガスとブラダの接触面における熱伝達は,

$$
\frac{d Q}{d t}=h A\left(T_{r}(0, t)-T(t)\right)
$$

でモデル化する.

なお, ブラダと容器壁の間に作動油が介在する場合があ る.この場合, 作動油が介在する分だけ散逸する熱エネル ギー量が低下すると推測され，ブラダが容器壁に直接接触 するFig. 2の場合の方が周囲に散逸する熱エネルギー量は 大きいと考えられる. そのため本研究では, ブラダが容器 壁に直接接触する場合のモデルを考えた. より詳細なモデ ルとして，ブラダと容器壁の間に作動油が介在するモデル が考えられるが，今後の研究課題である.

\section{3 窒素ガスの温度の時間変化}

Otis $^{1)}$ によれば，アキュムレータ内の窒素ガスの温度変化 の式は，次式で表わされる.

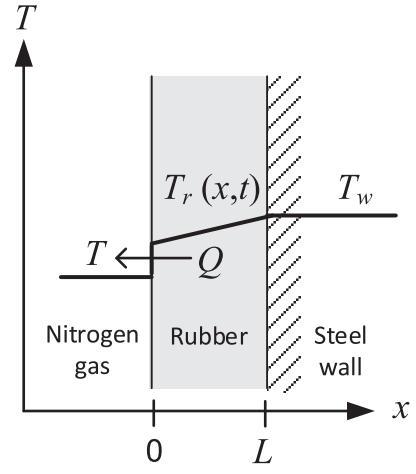

Fig. 2 Heat conduction and heat transfer of bladder-type accumulator

$$
\frac{d T}{d t}=\frac{1}{m C_{v}}\left[\frac{d Q}{d t}-T\left(\frac{\partial P}{\partial T}\right)_{V} \frac{d V}{d t}\right]
$$

ここで, van der Waalsの式(1)から,

$$
\left(\frac{\partial P}{\partial T}\right)_{V}=\frac{m R}{V-m b}
$$

であるから，これを式(11)に代入すれば次式を得る。

$$
\frac{d T}{d t}=\frac{1}{m C_{v}}\left[\frac{d Q}{d t}-\frac{m R T}{V-m b} \frac{d V}{d t}\right]
$$

窒素ガスの温度Tは, 式(13)を数值積分することにより求 める. その際, 窒素ガスの体積の時間変化 $d V / d t$ は, 後述す る実験結果より計測された值を代入した。熱伝達 $d Q / d t$ は, ピストン形の場合は式(7)から求める。 一方, ブラダ形の場 合は式(10)から求めるが, 窒素ガスとの接触面におけるゴム 表面の温度 $T_{r}(0, t)$ は, ゴム内部の熱伝導を考慮して求め る. ゴム内部の熱伝導の数值計算については, 4.4で詳しく 述べる. 窒素ガスの体積 $V$ と温度Tがわかれば, van der Waalsの式(1)から, 窒素ガスの圧力 $P$ 求めることができる.

\section{4 熱伝導方程式の数値解法}

ブラダのゴム内部の熱伝導の式(8)を有限差分近似すると, 次式を得る.

$$
\begin{aligned}
& \frac{T_{r}(i, j+1)-T_{r}(i, j)}{\Delta t} \\
& =\alpha \frac{T_{r}(i+1, j)-2 T_{r}(i, j)+T_{r}(i-1, j)}{(\Delta x)^{2}}
\end{aligned}
$$

ここで，iとjは，それぞれ厚さ方向の計算点の番号と時 間方向の計算点の番号を表わしている. パラメータ $\gamma$

$$
\gamma=\frac{\Delta t}{(\Delta x)^{2}}
$$

を用いて整理すれば，ブラダのゴム内部の温度を次式で求 めることができる.

$$
\begin{gathered}
T_{r}(i, j+1)=\gamma \alpha T_{r}(i+1, j)+(1-2 \gamma \alpha) T_{r}(i, j) \\
+\gamma \alpha T_{r}(i-1, j)
\end{gathered}
$$

ただし，数值計算が安定であるためには，

$$
\gamma \alpha \leq \frac{1}{2}
$$

が満たされなければならないことが知られている. $\gamma \alpha=$ 
$1 / 2$ とした場合, 式(16)の右辺第 2 項は零となり, 計算式 が簡単になる. この場合, 式(9)と式(15)から,

$$
\gamma \alpha=\frac{\Delta t}{\Delta x^{2}} \frac{k}{C_{r} \rho_{r}}
$$

であり, 厚さ方向の刻み幅は

$$
\Delta x=\sqrt{\frac{k \Delta t}{\gamma \alpha C_{r} \rho_{r}}}
$$

となる.一例として $, k=0.25 \mathrm{~W} /(\mathrm{m} \mathrm{K}), C_{r}=1960 \mathrm{~J} /(\mathrm{kg} \mathrm{K})$, $\rho_{r}=980 \mathrm{~kg} / \mathrm{m}^{3}, \Delta t=0.1 \mathrm{~s}, \gamma \alpha=1 / 2$ の場合, 厚さ方向の刻み

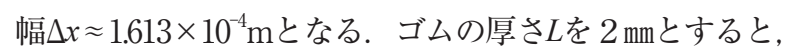

$$
\frac{L}{\Delta x}=\frac{2}{0.1613} \approx 13
$$

であるから, 厚さ方向に13分割されて, 差分近似されるこ とがわかる.

壁面に接触している面のゴムの温度は壁面の温度 $T_{w}$ に等 しいと仮定する．窒素ガスに接触している面の熱伝達は, 接触面におけるゴムの熱伝導に等しいと仮定する.

$$
h A\left\{T_{r}(0, t)-T\right\}=k A \frac{\partial T_{r}(0, t)}{\partial x}
$$

右辺の偏微分を有限差分近似し，

$$
\frac{\partial T_{r}(0, t)}{\partial x}=\frac{T_{r}(1, j+1)-T_{r}(0, j+1)}{\Delta x}
$$

これを式(21)に代入して, 窒素ガスに接触している面のゴム の温度 $T_{r}(0, j+1)$ について解けば, 次式を得る.

$$
\therefore T_{r}(0, j+1)=\frac{T_{r}(1, j+1)+\frac{h}{k} \Delta x T}{1+\frac{h}{k} \Delta x}
$$

初期状態では, ゴム内部の温度 $T_{r}$ は, 壁面の温度 $T_{w}$ に等 しく一様であると仮定する.

\section{5. アキュムレータの実験}

アキュムレータの実験装置をFig. 3に示す. ブラダ形ア

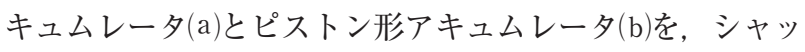
トオフ弁(e)をはさんで接続する。はじめに，止め弁(h)と(i), およびシャットオフ弁 $(\mathrm{e})$ を閉じ, 止め弁 $(\mathrm{g})$ と $(\mathrm{j})$ を開き, 油 圧ポンプ(f)により作動油をブラダ形アキュムレータ(a)に充

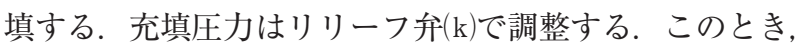
ピストン形アキュムレータ(b)のロッド側はタンク圧に開放 され, 封入した窒素ガスの圧力によってピストンは端まで 変位して停止し, 窒素ガスの体積は最大となる. 止め弁 $(\mathrm{g})$ と $(\mathrm{j})$ を閉じ，ポンプを停止して，この状態を約 7 時間保持 し，アキュムレータを含む油圧回路の温度がほぼ一定にな

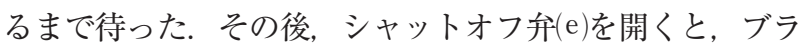
ダ形アキュムレータ (a)に充填されていた作動油が放出され, ピストン形アキュムレータ(b)に流入する. 絞り(1)は, 流入 流量を調整するために利用した。この際, ピストン形ア キュムレータ(b)のピストン変位をポテンショメータ(d)で測 定することで, 流入した作動油量を計算し, ガス体積の時
間変化を求めた. 2 個の圧力センサ $(\mathrm{c})$ によって, ブラダ形 およびピストン形アキュムレータの窒素ガスの圧力を, そ れぞれ測定した．なお，放出および充填の実験の際には， ピストン形アキュムレータとブラダ形アキュムレータは配 管を介して直結されており，ピストン形アキュムレータの ピストン変位をもとにブラダ形アキュムレータのガス体積 を求めることが出来る，ただし，ブラダ形アキュムレータ とピストン形アキュムレータの圧力の違いによる作動油体 積の変化を考慮するため, 作動油の圧縮性による体積変化 量を補正した。

実験では, 実験室の温度環境が実験結果の再現性に影響 した.アキュムレータに作動油を充填すると, 窒素ガスが 圧縮されることでガス温度が上昇し, 油圧回路の温度を上 昇させる. そのため, 約 7 時間かけて, これらの温度がで きるだけ室温に戻るまで待機した。 さらに，日射の影響を 防ぐために, 空を黒い紙で覆い, あわせてクーラーを作動 させて室温ができるだけ一定になるようにした。

アキュムレータモデルの計算にあたり, 封入された窒素 ガスのモル数 $m$ を知る必要がある. 封入時の窒素ガスの圧 力 $P_{0}$, 体積 $V_{0}$, および温度 $T_{0}$ をvan der Waals方程式に代入 すると

$$
\left(P_{0}+\frac{a m^{2}}{V_{0}^{2}}\right)\left(V_{0}-m b\right)=m R T_{0}
$$

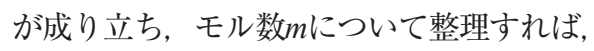

$$
\frac{a b}{V_{0}^{2}} m^{3}-\frac{a}{V_{0}} m^{2}+\left(R T_{0}+P_{0} b\right) m-P_{0} V_{0}=0
$$

を得る. この 3 次代数方程式の実数根がモル数 $m$ である. ブラダ形およびピストン形のそれぞれのアキュムレータに ついて, モル数を求めた.

(a)

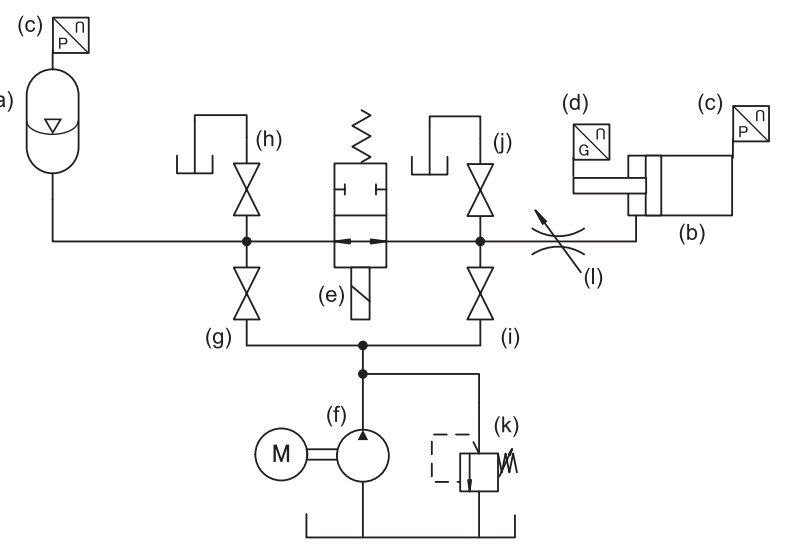

Fig. 3 Experimental setup using a bladder-type accumulator and a piston-type accumulator

\section{6. アキュムレータモデルの検証}

はじめにブラダ形アキュムレータに作動油を充填してお き, シャットオフ弁を開くことで作動油を放出, ピストン 形アキュムレータに充填する実験を行った. ブラダ形ア 
キュムレータの放出過程の実験結果をFig. 4に示す。横軸 は窒素ガス体積 $V$ を, 縦軸は窒素ガス圧力 $P$ を表している.

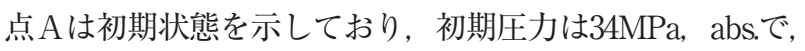
初期ガス体積は $2.65 \mathrm{~L}\left(2.65 \times 10^{-3} \mathrm{~m}^{3}\right)$ であった. なお, 周囲 温度は301Kであった，放出によって，ガス体積は $5 \mathrm{~L}$ に膨 張して, 点 Bの状態に到達する. 膨張過程の時間は 10 sと した，実線は実験結果を，点線はvan der Waals（vdW）の 断熱変化の式(5)を，また一点鎖線はvan der Waalsの等温変 化の式(4)を表す．破線は，4.2で提案したブラダ形アキュム レータモデルによる計算結果であり, 熱伝達係数 $h$ を $5 \mathrm{~J} /$ $\left(\mathrm{s} \mathrm{m}^{2} \mathrm{~K}\right)$, 熱伝達面積 $A=0.27 \mathrm{~m}^{2}$ とした. 破線で示す本モデ ルのシミュレーション結果は, ほほ断熱変化に近く, 実験 結果をよく再現している. なお, 接触面近傍の窒素ガスの 流れや温度境界層, ブラダ形状などの要因が熱伝達に複雑 に影響するために, 熱伝達係数 $h$ を求めることは困難であ る. 窒素ガスから周囲への熱伝達が全くない場合は完全な 断熱変化であるが, この場合の熱伝達係数hは 0 である. 熱伝達係数hが大きいほど, 熱伝達量も大きい. 本研究の シミュレーションでは, 実験結果を参考に, 熱伝達係数 $h$ を調整して定めた.

次に, 窒素ガスの状態変化に理想気体の状態方程式を用 いて計算した (Ideal + Otis). 定容比熱 $C_{v}(20.8 \mathrm{~J} /(\mathrm{mol} \mathrm{K}))$, 熱伝達に関わる表面積 $A\left(0.27 \mathrm{~m}^{2}\right)$, 熱伝達係数 $h\left(5 \mathrm{~J} /\left(\mathrm{s} \mathrm{m}^{2} \mathrm{~K}\right)\right)$

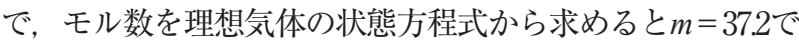
あるから，熱時定数を計算すると $\tau=573 \mathrm{~s}$ となった，点 $\mathrm{A} の$ 初期状態ではガス体積 $V_{0}=2.65 \times 10^{-3} \mathrm{~m}^{3}$, ガス圧力 $P_{0}=$ $34 \mathrm{MPa}$, abs.であり, 点Bでのガス体積 $V_{1}=5.0 \times 10^{-3} \mathrm{~m}^{3}$ であ る. 理想気体の断熱の式から, 点Bにおける圧力 $P_{1}$ は,

$$
P_{1}=P_{0}\left(\frac{V_{0}}{V_{1}}\right)^{\kappa}=34 \times\left(\frac{2.65}{5}\right)^{1.4} \approx 14 \mathrm{MPa} \text {, abs. }
$$

となり, 点 $\mathrm{B} の$ 実験結果との差異は顕著である. このこと から，本実験のような圧力では，理想気体ではなく，実在 気体モデルを考慮する必要があることがわかる.

次に, ゴムの熱伝導を無視し, 熱時定数を考慮し, 窒素 ガスの状態変化として, van der Waals方程式を用いた場合 をシミュレーションした $(\mathrm{vdW}+\mathrm{Otis})$ ）具体的には，窒素 ガスの温度変化の式(13)における $\mathrm{dQ} / \mathrm{dt}$ の計算に，式(7)を用 いることに相当する. 定容比熱 $C_{v}(20.8 \mathrm{~J} /(\mathrm{mol} \mathrm{K}))$, 熱伝達 に関わる表面積 $A\left(0.27 \mathrm{~m}^{2}\right)$, 熱伝達係数 $h\left(5 \mathrm{~J} /\left(\mathrm{s} \mathrm{m}^{2} \mathrm{~K}\right)\right)$ で

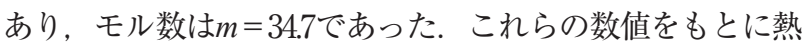
時定数を計算すると $\tau=m C_{v} /(h A)=534 \mathrm{~s}$ となる. ゴムの熱伝 導を無視し, van der Waals方程式とOtisの熱時定数モデル を組み合わせたシミュレーション結果（vdW + Otis）と， 破線で示される本手法（式(10)）のシミュレーション結果 （van der Waals）を比較するとわずかながら違いがみられ るが，顕著な差異ではない.

参考文献 9）では，ブラダ形アキュムレータの実験結果 から, ブラダによる断熱効果が認められるため, エネル
ギー回生回路ではブラダ形アキュムレータの利用を推奨し ているが, ブラダの熱伝導を考慮したシミュレーションま では行っていない. シミュレーションにおいてブラダの断 熱効果を考慮するためには，ブラダの熱伝導をモデル化す ることが物理現象の観点から必要であると考える．本研究 の意義は，その第一歩として，ブラダの熱伝導を考慮した モデルを提案したことにある.

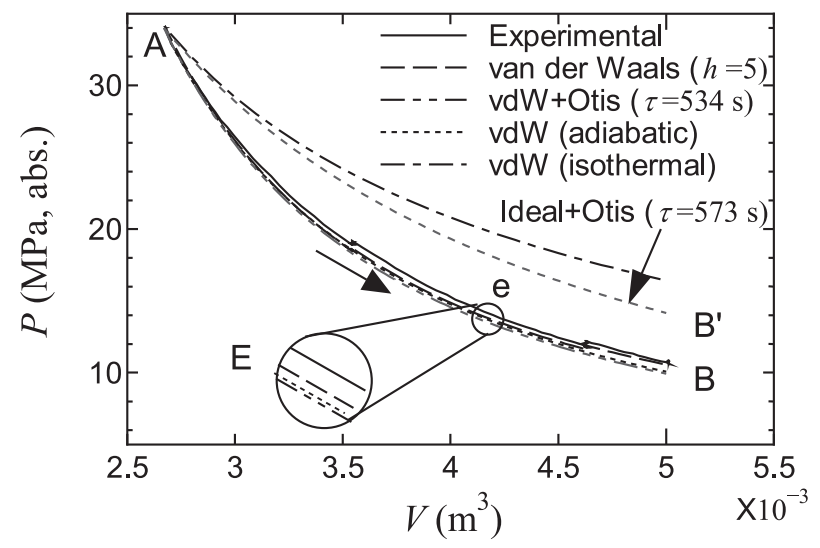

Fig. 4 PV-diagram of a discharge test of bladder-type accumulator (10s, 301K)

一方, Fig. 5は, 同時に測定された, ピストン形アキュ ムレータの充填過程のPV線図である. 点A は初期状態で あり，窒素ガスの体積は7.4L，圧力は4.4MPa，abs.であった. 点 $\mathrm{B}$ は, 圧縮直後の状態であり, 窒素ガスは体積 $5 \mathrm{~L}$ で 圧縮された．実線は実験結果を示す。破線は，4.1に示した ピストン形アキュムレータモデルの計算結果 $(h=5 \mathrm{~J} /(\mathrm{s}$ $\left.\left.\mathrm{m}^{2} \mathrm{~K}\right), A=0.21 \mathrm{~m}^{2}\right)$ であり, 実験結果をよく再現している. この場合, モル数 $m=23.3, C_{v}=20.8 \mathrm{~J} /(\mathrm{mol} \mathrm{K}), A=0.27 \mathrm{~m}^{2}$, $h=5 \mathrm{~J} /\left(\mathrm{s} \mathrm{m}^{2} \mathrm{~K}\right)$ であり, これらの数值をもとに熱時定数

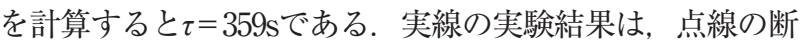
熱特性から若干離れている。これは, ピストン形の場合, 窒素ガスが直接壁面に接触するので, 窒素ガスの熱エネル ギーが熱伝達によって壁面に伝わり，周囲に拡散する影響 であると推察される. 一方, Fig. 4に示す, ブラダ形アキュ ムレータでは，窒素ガスはゴム製のブラダに接触している. 容器の鋼鉄の熱伝導率はおよそ $50 \mathrm{~W} /(\mathrm{m} \mathrm{K})$ であるが，ゴ ムの熱伝導率は, 例えば, $0.25 \mathrm{~W} /(\mathrm{m} \mathrm{K})$ 程度であり, ゴ ムはある程度断熱材としての効果 ${ }^{9}$ を持つため, より断熱 に近い特性が現れた結果であると推察される，4.2に示した ブラダ形アキュムレータのモデルでは，ブラダのゴム内部 の熱伝導を考慮してモデル化されており，Fig.4に示すよ うに，実験結果をよく再現している。

窒素ガスの温度変化に伴い, ブラダ内の温度分布も変化 する．本実験では，充填放出の時間を10秒としたが，充填 放出時間をより短く設定して窒素ガスの温度が極短時間で 変化した場合，ブラダ内の温度分布はより遅れて変化する と推察されるが, その影響については今後の研究課題とし 
たい．なお，本実験装置で充填放出時間を極短くした場合， ピストンが滑らかに運動しない場合が見受けられたため, ピストンが滑らかに運動し，かつできるだけ短い時間とし て10秒の場合の実験結果を示した.

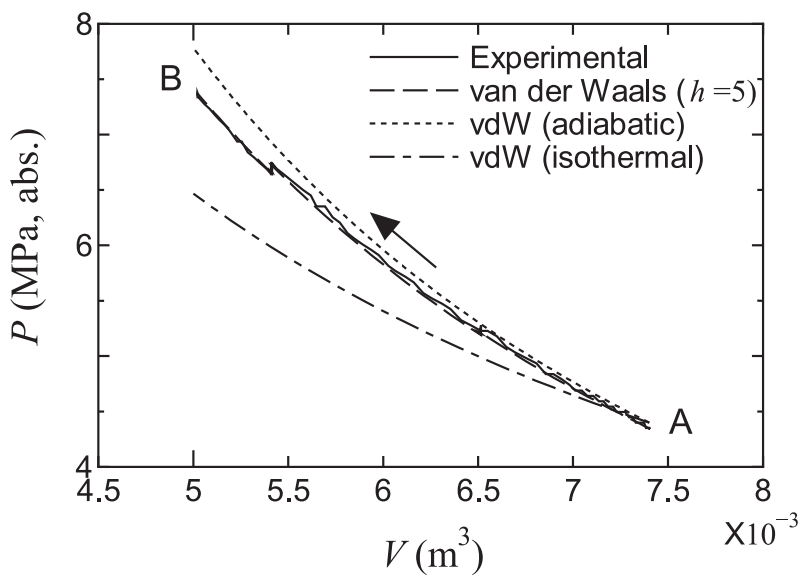

Fig. 5 PV-diagram of a charge test of piston-type accumulator (10s, 301K)

次に, はじめにピストン形アキュムレータに作動油を充 填しておき，シャットオフ弁を開くことで，ピストン形ア キュムレータの作動油を放出，ブラダ形アキュムレータを 充填する実験を行った. 実験結果の一例を, Fig. 6 とFig. 7 に示す．周囲温度は296Kであった．充填放出にかける時間 を長くして，できるだけ温度変化を抑制するように，充填 放出時間を 8 時間とした．充填放出時間を長時間化するた めに，絞り(1)を絞ると同時に，シャットオフ弁(e)を間欠的 に開閉する方法をとった。

ブラダ形アキュムレータの充填過程の実験結果をFig. 6 に示す．点 Aが初期状態であり，ガス体積は $5 \mathrm{~L}$ ， ガス圧 力は11MPa, abs.であった. 点 Bは充填直後の状態であり, ガス体積は3.5Lに圧縮され，ガス圧力はおよそ $15.6 \mathrm{MPa}$, abs.まで増加した。実線の実験結果は, 一点鎖線で示され るvan der Waalsの等温変化の式(4)に近い。また，破線は4.2 で提案したブラダ形アキュムレータのモデルによる計算結 果で, 熱伝達係数 $h$ は $1000 \mathrm{~J} /\left(\mathrm{s} \mathrm{m}^{2} \mathrm{~K}\right)$, 熱伝達面積 $A=0.27 \mathrm{~m}^{2}$ とした。 ブラダ形アキュムレータモデルによる計算結果は, 実験結果をよく再現している. なお，Fig.6とFig.7では， 実験結果を参考に，熱伝達係数 $h$ 調整して $1000 \mathrm{~J} /\left(\mathrm{s} \mathrm{m}^{2} \mathrm{~K}\right)$ と定めた

Fig. 6に熱時定数モデルおよび理想気体モデルのシミュ レーション結果を重ねて描いた，van der Waals方程式と熱 時定数モデルを組み合わせたシミュレーション結果（vdW +Otis） と，理想気体の状態方程式と熱時定数を組み合わ せたシミュレーション結果 (Ideal+Otis) は, 破線で示さ れる本手法（式(10)）のシミュレーション結果や実線の実験 結果と大きな差異は現れなかった. 本実験では, 充填を十 分長い時間をかけて行ったため, ブラダの熱伝導の影響は
顕著ではなかった.

同時に計測した，ピストン形アキュムレータの放出過程 の実験結果をFig. 7に示す。実線の実験結果は, 一点鎖線 で示されるvan der Waalsの等温変化の式(4)に近いが, 若干 の差が現れている. 熱伝達係数 $れ は 1000 \mathrm{~J} /\left(\mathrm{s} \mathrm{m}^{2} \mathrm{~K}\right)$, 熱伝達 面積 $A=0.21 \mathrm{~m}^{2}$ とした. 4.1に示したピストン形アキュムレー タモデルの計算結果は, 破線で示されており, 実験結果を 再現している.

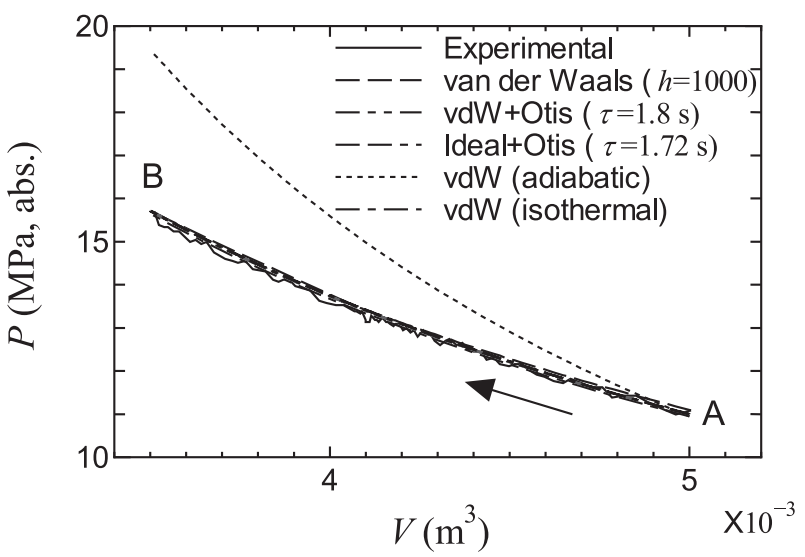

Fig. 6 PV-diagram of a charge test of bladder-type accumulator (8hours, 296K)

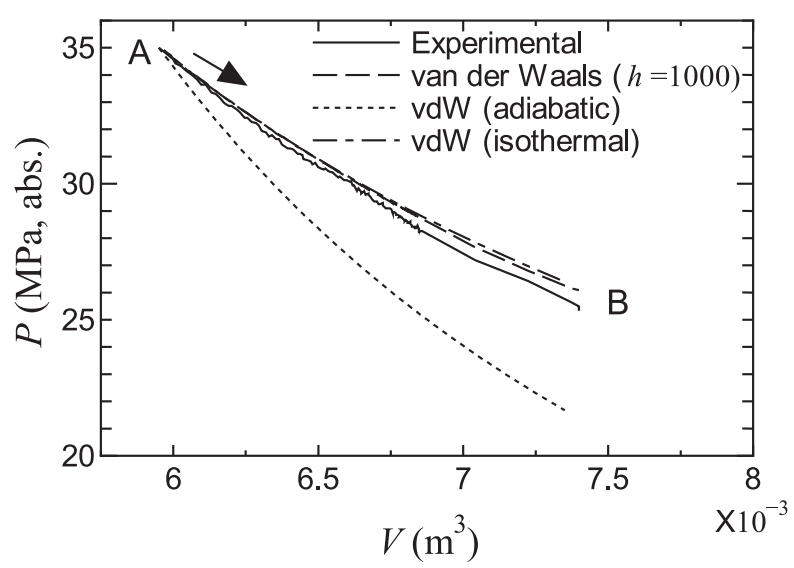

Fig. 7 PV-diagram of a discharge test of piston-type accumulator (8hours, 296K)

\section{7. 結 言}

本論文では，ブラダのゴム内部の熱伝導を考慮したブラ ダ形アキュムレータの数学モデルを提案した．具体的には, 窒素ガスとゴムの接触面では熱伝達を考慮し, ゴム内部で は厚さ方向の 1 次元熱伝導を考慮してモデル化した. 窒素 ガスの実在気体モデルとして, van der Waals方程式を利用 した. さらに, ブラダ形アキュムレータとピストン形ア キュムレータを接続した実験装置を製作した。本実験装置 では，ブラダ形アキュムレータとピストン形アキュムレー 夕の充填過程および放出過程の実験を同時に行うことがで きる、本モデルによる計算結果は，ブラダ形アキュムレー 
夕の実験結果をよく再現することが示された. van der Waals方程式は, 等温過程と断熱過程の式が容易に利用で きる利点がある，今後，より高精度であると言われ ${ }^{10)}$ ，市 販シミュレーションソフトにも使用されている実在気体モ デルであるSoave-Redlich-Kwong方程式 ${ }^{11)}$ 利用したアキュ ムレータの数学モデルを構築することが課題の一つである.

\section{謝辞}

本研究を進めるにあたり，東京工業大学名誉教授，香川 利春先生，北川能先生に，ご指導を賜りました。また，実 験にあたり，日本アキュムレータ株式会社のご協力を頂き ました，誌上をお借りして，謝意を表します。

\section{参 考 文 献}

1) Otis, D.R. : New Developments in Predicting and Modifying Performance of Hydraulic Accumulators, National Conference on Fluid Power, p. 473-489 (1974)

2 ) Obert, E.F. : Concepts of Thermodynamics, McGraw Hill Book Co., p. 240 (1960)

3 ) Elder, F.T., Otis, D.R. : Accumulators : The Role of Heat Transfer in Fluid Power Losses, 4th International FLUID POWER SYMPOSIUM, p. D2-27-D2-37 (1975)

4) Pourmovahed, A., Otis, D.R. : An Experimental Thermal Time-Constant Correlation for Hydraulic Accumulator, Transactions of the ASME, Journal of Dynamic Systems, Measurement, and Control, Vol. 112, March, p. 116-121 (1990)
5 ) Pourmovahed,A.,Beachley,N.H.,Fronczak,F.J. : Modeling of a Hydraulic Energy Regeneration System-Part I : Analytical Treatment, Transactions of the ASME, Journal of Dynamic Systems, Measurement, and Control, Vol. 114, March, p. 155-159 (1992)

6 ) Pourmovahed,A.,Beachley,N.H.,Fronczak,F.J. : Modeling of a Hydraulic Energy Regeneration System-Part II : Experimental Program, Transactions of the ASME, Journal of Dynamic Systems, Measurement, and Control, Vol. 114, March, p. 160-165 (1992)

7) Rupprecht, K.R. : Austauschvorgänge bei Hydrospeichern, ölhydraulik und pneumatic, Vol. $30 \mathrm{Nr}$. 1, p. 42-47 (1986)

8 ) Bender, G. et. al. : Hydrospeicher als Energiespeicher, ölhydraulik und pneumatic, Vol. 32 Nr. 3, p. 188-193 (1988)

9 ) Juhala, J. Kajaste, J., Pietola, M. : Experimental Analysis of HeatLosses in Different Types of Hydraulic Accumulators, Proceedings of the 8th FPNI Ph. D Symposium on Fluid Power FPNI2014, FPNI2014-7838 (2014)

10) Henrik Brun Hansen, Peter Windfeld Rasmussen : Modeling Hydraulic Accumulators for use in Wind Turbines, The 13th Scandinavian International Conference on Fluid Power, p. 327-334 (2013)

11) G. Soave : Equilibrium constants from a modified RedlichKwong equation of state, Chemical Engineering Science, Vol. 27, pp. 1197-1203（1972） 